October 1999 • NREL/SR-550-27123

\title{
A Comprehensive Review of Market Research on Solar Water Heaters
}

\author{
P. Ghent and C. Keller \\ Focus Marketing Services \\ Westlake Village, California
}

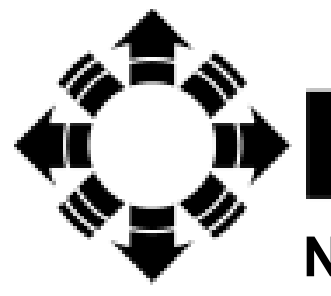

National Renewable Energy Laboratory

1617 Cole Boulevard

Golden, Colorado 80401-3393

NREL is a U.S. Department of Energy Laboratory

Operated by Midwest Research Institute • Battelle $\bullet$ Bechtel

Contract No. DE-AC36-98-G010337 
October 1999 • NREL/SR-550-27123

\section{A Comprehensive Review of Market Research on Solar Water Heaters}

P. Ghent and C. Keller

Focus Marketing Services

Westlake Village, California

NREL Technical Monitor: R. Hewett

Prepared under Subcontract No. AAR-9-18498-01

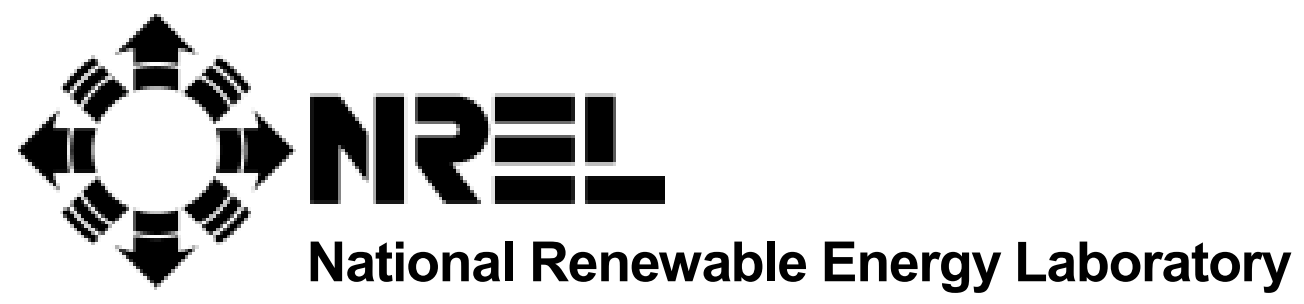

1617 Cole Boulevard

Golden, Colorado 80401-3393

NREL is a U.S. Department of Energy Laboratory

Operated by Midwest Research Institute • Battelle $\bullet$ Bechtel

Contract No. DE-AC36-98-G010337 


\section{NOTICE}

This report was prepared as an account of work sponsored by an agency of the United States government. Neither the United States government nor any agency thereof, nor any of their employees, makes any warranty, express or implied, or assumes any legal liability or responsibility for the accuracy, completeness, or usefulness of any information, apparatus, product, or process disclosed, or represents that its use would not infringe privately owned rights. Reference herein to any specific commercial product, process, or service by trade name, trademark, manufacturer, or otherwise does not necessarily constitute or imply its endorsement, recommendation, or favoring by the United States government or any agency thereof. The views and opinions of authors expressed herein do not necessarily state or reflect those of the United States government or any agency thereof.

Available electronically at http://www.doe.gov/bridge

Available for a processing fee to U.S. Department of Energy and its contractors, in paper, from:

U.S. Department of Energy

Office of Scientific and Technical Information

P.O. Box 62

Oak Ridge, TN 37831-0062

phone: 865.576 .8401

fax: 865.576.5728

email: reports@adonis.osti.gov

Available for sale to the public, in paper, from:

U.S. Department of Commerce

National Technical Information Service

5285 Port Royal Road

Springfield, VA 22161

phone: 800.553 .6847

fax: 703.605.6900

email: orders@ntis.fedworld.gov

online ordering: http://www.ntis.gov/ordering.htm

This publication received minimal editorial review at NREL 


\title{
A Comprehensive Review of Market Research on Solar Water Heaters
}

\author{
Final Report on Task 2 of a Four-Task Project \\ Presented To: \\ Russell Hewett \\ National Renewable Energy Laboratory \\ Submitted By: \\ Peer Ghent \\ Cynthia Keller \\ Focus Marketing Services
}

\section{Objective}

The objective of this task is to identify key elements in previous studies on the marketing of solar water heaters in the new home industry. This review includes studies performed by FOCUS Marketing Services, the National Association of Home Builders Research Center, Symmetrics Marketing Corporation, and the California Energy Commission.

\section{Methodology}

Team members reviewed the specified reports and analyzed the key messages of each report. The appendix to this report contains the team's summary of the findings, conclusions, and recommendations from each of the reports. These factors were considered in conjunction with the extensive knowledge and building industry background of the members of the FOCUS team.

The review took into account the concerns of homebuilders and home buyers, and the real and perceived strengths and weaknesses of solar water heating products. The results of this review are presented in this report, to be used as the basis of developing the marketing plan and recommendations that will become part of Task 3.

\section{Overview}

The previous studies were targeted to different audiences, had distinct study objectives, and used various quantitative and qualitative research methodologies. Although there were some discrepancies in their detailed findings, there were several common conclusions that are pertinent for further consideration.

This report is organized around these conclusions. For each major conclusion or "key message," this report cites at least four of the previous reports. In addition, the team has added the marketing implications of these messages. 


\section{Previous Reports}

The following legend was used to reference the previous reports:

\begin{tabular}{|l|l|}
\hline Legend Key & \multicolumn{1}{|c|}{ Report } \\
\hline NAHB & $\begin{array}{l}\text { "Opportunities for Solar Water Heating," NAHB Research Center, January } \\
1998 .\end{array}$ \\
\hline FOCUS 1 & $\begin{array}{l}\text { "Solar Water Heating Quantitative Survey (Report on)," Quantitative } \\
\text { Research, Findings, Conclusions and Recommendations, Focus Marketing } \\
\text { Services, April 1999. }\end{array}$ \\
\hline FOCUS 2 & $\begin{array}{l}\text { "Solar Water Heating Qualitative Survey (Report on)," Qualitative Research, } \\
\text { Findings, Conclusions and Recommendations, Focus Marketing Services, } \\
\text { January 28, 1998. }\end{array}$ \\
\hline CEC & $\begin{array}{l}\text { "New Home Buyer Solar Water Heater Trade-off Study", Symmetrics } \\
\text { Marketing Corporation, June 1999. }\end{array}$ \\
\hline & $\begin{array}{l}\text { "Analysis of Various Water Heating Systems", California Energy } \\
\text { Commission, May 1996. }\end{array}$ \\
\hline
\end{tabular}

\section{Key Messages}

1. Most people know about solar water heating, but are not familiar with current technology. Many have negative impressions based upon the early rush to solar.

- Solar has a negative image with many consumers.

- Early applications were ugly.

- Consumers are insecure about system reliability.

- Builders and consumers believe solar systems are expensive to install and maintain.

\section{References}

\section{NAHB}

"In all groups, respondents had some familiarity with solar water heating" p. 2

"Many builders had negative top-of-mind reactions to the term "solar water heating.", p.2

"Builder expectations that solar water heating systems would be unattractive were confirmed by Photos 1 and 2 ...", p. 2.

"There was generally a limited understanding by builders about the costs for currently available solar water heating systems. They perceived that they were significantly more expensive than they actually are.", p. 3. 


\section{FOCUS 2}

“...respondents ... admit they have little knowledge of solar energy. And the images they do have of solar equipment are negative in terms of appearance, function, maintenance and cost. For many, solar energy is something they consciously reject.", p. 4.

“...non-users express strong concerns about the appearance, reliability and maintenance expenses associated with solar systems...", p. 4.

\section{FOCUS 1}

"While a large portion of respondents are aware that solar water heating does exist, it is not something that is top-of-mind, or something they think about when looking for a new home." p. 3.

“...many respondents express concern about the overall economics of installing a solar system.", p. 4.

\section{SYM}

"While solar water heaters suffer from a bad reputation, the new solar technology has potential with new home buyers.", p. 39.

"Home buyers currently have clear perceptions of the disadvantages of solar water heaters.", p. 39.

\section{Marketing Implications}

- "Solar marketers need to eliminate perceived disadvantages - high initial cost, unattractive, unreliable, vulnerable to bad weather." (SYM, p. 39)

- New solar technologies must be showcased for consumers to see for themselves that the new solar roof collectors are aesthetically appealing.

- Consumer concerns about reliability cannot be satisfied from short run experience with the product. Instead, their confidence must be satisfied by one or more of the following -- the reputation of the manufacturer, brand recognition, the reputation of the installer, the reputation of the builder, the strength of the product warranty and/or the third party sponsor (utility company, governmental body, etc.).

2. If a consumer is attracted to solar water heating, the major advantage considered is lower energy costs. Although using solar energy has some environmental appeal, the utility industry has done a good job convincing the consumers that gas and electricity are "clean" alternatives.

- The current depressed market for gasoline has made consumers less concerned about saving nonrenewable energy sources. (This is an observation of the Focus team, not mentioned in the earlier reports.)

- When natural gas is available, the relative economics of solar water heating are not obvious to the consumer. 
- Electricity is considered a high cost alternative. Most consumers are easily convinced that a combination of solar and electric is more economical than electric alone for water heating.

\section{References}

\section{NAHB}

"Most respondents offered natural gas water heaters if they were available because they were thought to be less expensive to operate, have quicker heat recovery, and were preferred by most customers.", p. 1.

“...criteria for choosing a water heating system. Cost, efficiency, and recovery time were the most frequently cited attributes that were important to builders. ... were directly related to meeting customer expectations.", p. 1 and 2.

"Builders felt that consumers did not want to think about their water heating system or maintenance, and that, despite being concerned about the environment, home owners are more concerned about price, aesthetics, and resale.", p. 3.

\section{FOCUS 2}

"Demonstrating both short and long-term money savings that are possible when using solar water heating in a straightforward and believable manner is the key to increasing sales of these systems.", p. 4. "...it is nice to do what you can to help the environment, but did not/would not base their purchase decision upon environmental factors.", p. 5.

\section{FOCUS 1}

"Four of the five most important purchase decision factors focus on the overall financial picture maintenance required, warranty provided, monthly money savings, and fully installed price.”, p. 4.

\section{SYM}

"The major perceived advantage to solar is lower energy costs...", p. 39.

"Interest in solar water heaters was largely driven by price and performance...", p. 43.

\section{CEC}

“...shows gas water heating less expensive on a life-cycle basis than electric water heating when natural gas is available.", p. 1.

"Among the natural gas water heating options in the Sacramento area, conventional gas water heaters appear more cost effective than solar water heaters using these gas water heaters as their backup.", p. 1. "A combined ICS-propane gas system becomes the least cost option when natural gas is not available.", p. 1.

"Among electric water heating systems, the least cost system based on life-cycle costs is an ICS-electric system. The next least cost system is an active solar-electric water heater.", p. 1. 


\section{Marketing Implications}

- "Solar marketers need to be able to demonstrate cost advantage and payback to home buyers." (SYM, p. 39)

- Markets currently without natural gas offer the best potential for solar water heating to gain market share. The economic advantage of solar can be demonstrated conclusively.

- Solar water heater manufacturers can influence the economics of their systems by increasing efficiency and lowering initial system costs. "If they can focus on increased efficiency while reducing costs, keeping reliability high and maintenance low, they have the opportunity to produce systems which are more cost-effective than simple gas water heating systems." (CEC, p. 2)

- "Solar marketers need to determine what type of unit can satisfy this price/performance trade-off." (SYM, p. 43)

\section{After learning about current technology and product options, consumers were more likely to consider purchasing a solar water heating system.}

- Builders and consumers were favorable to the appearance of the latest roof collectors.

- After being made aware of what was available in solar, consumers said they would consider solar water heating.

\section{References}

\section{NAHB}

"...they [builders] thought the system shown in the third photograph was attractive. Contractors...thought the second and third photos were attractive.", p. 2.

\section{FOCUS 2}

"After being exposed to the newer solar panels, non-users unanimously agree that they would not steer away from a home equipped with this type of system, especially if it saved them money.", p. 5.

“...non-users...would accept solar if offered as a standard on a home. However, most would be suspicious of a builder offering solar water heating as an upgrade, assuming they were pushing this equipment as an added profit center, rather than as something beneficial for the buyer.”, p. 5. "Consumers are also much more likely to purchase a solar system from the builder as the home is being built because they view the installation as being much more simple and safe in terms of the roof warranty during the construction stage.", p. 5.

"The newer versions of solar panels are significantly more appealing...than the older, larger panes.", p. 6. “...users...are very committed to solar energy.", p. 7. 


\section{FOCUS 1}

"Over nine in ten respondents (96\%) did not consider solar water heating when they recently purchased their new home...", p. 3.

"...over three-fourths of all respondents indicate that if their builder had recommended solar they would have either seriously considered it or wanted to learn more.", p. 3.

"There appears to be a sizable amount of interest in the newer types of solar water heating systems, assuming the solar industry can make these systems readily available and can generate much stronger awareness of these systems among home buyers.", p. 4.

\section{SYM}

"Interest in solar water heaters increased substantially once home buyers were 'educated' about the new technology.", p. 39.

"People were more likely to be interested in solar...if they had some prior experience with solar...", p. 41.

\section{Marketing Implications}

- "The success of solar water heaters is dependent upon multiple players: manufacturers, builders, realtors, consumers." (SYM, p. 44)

- "Solar marketers need to demonstrate to builders that there IS consumer interest in the product." (SYM, p. 44)

- "Consumers will adopt solar if

- the cost/benefit is favorable to them

- builders/realtors push the product" (SYM, p. 44)

- "...the solar industry needs to clearly communicate the facts that the new solar systems come with strong warranties and are relatively maintenance free." (FOCUS 2, p. 4)

- The ability to deliver a strong statement of savings would increase the builder's ability to sell solar water hearing to their customers.

- Offering energy efficient products as standard features and implementing a strong marketing campaign can differentiate the builder's product from competitors. Making solar water heating standard should also reduce the delivered cost to the consumer. 


\section{APPENDIX}

Working Paper

Key Points From Previous Reports 


\begin{tabular}{|c|c|}
\hline Key Message & Page \\
\hline $\begin{array}{l}\text { NAHB Research Center (NAHB) } \\
\text { Eight focus groups with builders, contractors, and architects to understand } \\
\text { regional differences in construction practices and familiarity with solar water } \\
\text { heating. }\end{array}$ & \\
\hline $\begin{array}{l}\text { Builders said their decision on water heaters is based on low first cost and consumer } \\
\text { preference. } \\
\text { Plumbers include the cost in the total fixed price bid for piping, fixtures and faucets. } \\
\text { Gas units are perceived as having a higher installed cost - all houses must have } \\
\text { electricity, but gas lines must be run for gas water heaters and other gas appliances. }\end{array}$ & 1 \\
\hline $\begin{array}{l}\text { Natural gas offered if available - less expensive to operate, quicker heat recovery and } \\
\text { preferred by consumers. }\end{array}$ & 1 \\
\hline $\begin{array}{l}\text { Builders consider home buyers the key decision maker for a water heater, } \\
\text { Architects consider themselves the key decision maker, } \\
\text { Contractors consider themselves key. }\end{array}$ & 1 \\
\hline $\begin{array}{l}\text { Custom/luxury builders offer several options to reduce hot water delivery time - } \\
\text { recirculating pumps, heat recovery systems, multiple water heaters and solar water } \\
\text { heating. }\end{array}$ & 1 \\
\hline $\begin{array}{l}\text { Title } 24 \text { and California Energy Code led starter and move-up builders in Sacramento } \\
\text { to suggest the construction trade-offs needed to compensate for the inefficiency of } \\
\text { electric water heaters made them prohibitively expensive. }\end{array}$ & 1 \\
\hline $\begin{array}{l}\text { Criteria for choosing a water heating system varied by type of respondent. } \\
\text { Builders - cost, efficiency and recovery time. Meeting customer expectations. } \\
\text { Architects - availability, code acceptance, home owner preference, recovery time, } \\
\text { warranty, worker familiarity with installation and impact on the builder. } \\
\text { Contractors - some positive and some negative responses to both active and passive } \\
\text { [solar water] heating. }\end{array}$ & $1 \& 2$ \\
\hline All were somewhat familiar with solar water heating. & 2 \\
\hline $\begin{array}{l}\text { Builders are negative to the term "solar water heating", and skeptical about cost- } \\
\text { effectiveness. Fear of roof leaks and thought solar collectors were ugly. } \\
\text { Architects are positive on active solar in areas not subject to freezing, but are negative } \\
\text { on passive systems. }\end{array}$ & 2 \\
\hline Architect comments on passive systems: bummer, freezing, leaks, panel problems. & 29 \\
\hline $\begin{array}{l}\text { When a community is against solar, it is difficult for builders and architects to use it } \\
\text { on their homes. }\end{array}$ & 2 \\
\hline $\begin{array}{l}\text { Builders are interested in whether solar will work and not cause difficulties over time. } \\
\text { Architects want solar to be as reliable and unobtrusive as conventional water heaters. }\end{array}$ & 2 \\
\hline $\begin{array}{l}\text { Several trade contractors are concerned about the impact a solar water heater would } \\
\text { have on the construction process and labor costs. }\end{array}$ & 2 \\
\hline Contractors believed the installation needs to be simplified and standardized. & 2 \\
\hline Builders perceived solar to be more expensive than it is. & $2 \& 3$ \\
\hline Architects are concerned about economics of solar - it should not cost more. & 3 \\
\hline Builders think consumers do not want to think about their water heating system. & 3 \\
\hline Architects think consumer worries about aesthetics, maintenance and monthly cost. & 3 \\
\hline $\begin{array}{l}\text { There is disagreement over who should install SWH. Orlando thought specialty } \\
\text { contractors, Sacramento felt existing contractors should install and Phoenix move-up } \\
\text { builder thought a large plumbing contractor would be ideal. }\end{array}$ & 3 \\
\hline Concern over the solar collector on the roof causing leaks. & 2 \\
\hline $\begin{array}{l}\text { Architects suggest solar water heating may cause construction interface problems with } \\
\text { electricity, plumbing and framing. }\end{array}$ & 31 \\
\hline
\end{tabular}


Group recommendations to the solar industry:

- Improved marketing, aesthetics, installation, image and design.

- Make it affordable

- Educate consumers

- Technical assistance and a good warranty

- Incentives/rebates, product support, knowledgeable contractors, good performance data, and reliability.

Also recommended forming partnerships with the government, utilities, manufacturers, suppliers, distributors, and/or builders.

Builders need to be able to make money on offering the product and they are concerned whether or not the buyer will pay more.

Contractors felt a major brand name on the product would be a benefit.

NAHB Conclusions

- Appearance is the biggest concern for SWH.

- Builders and buyers are very satisfied with existing gas water heaters - desired recovery time and reliability.

- Past state and Federal incentive programs tainted the word "solar". ("Fly-bynight" contractors and poor product contributed to the bad impressions.)

- Builders, who build for market demand, do not perceive a consumer demand for solar.

- Architects influence the high-end market and are open to solar.

- Plumbers want to install SWH if it going to be installed.

NAHB Recommendations

- Conduct application engineering, field testing, and market demonstrations with opinion leading builders and their trade contractors to integrate SWHs into new residential construction.

- Conduct market research on effective messages and channels for creating builder and consumer demand.

- Address solar collector design issues through charrettes with architects.

Symmetrics Marketing Corp. (Sym)

Sponsored by SRP and NREL.

Research in the Phoenix and Las Vegas markets to determine "utility" or

importance of the solar water heater vis-à-vis other features.

Identify demographic and psychographic characteristics of new home buyer

that correlate with the perceived utility of the solar water heater.

Identify features of the solar water heater, itself, most valued by new home buyers.

\section{Sym Conclusions}

- Solar water heaters suffer from a bad reputation, but new solar technology shows promise.

- Interest in solar increased after home buyer was "educated" about the new technology.

- Major perceived advantage to solar is lower energy costs.

- Perceived disadvantages are strong and include high initial cost, unattractive, unreliable, vulnerable to bad weather.

- For the study group, energy efficient windows and appliances were more popular with home buyers, but solar was ahead of others such as countertops, home security or fireplace. 


\begin{tabular}{|c|c|}
\hline - On average, home buyers would rather see a price reduction of $\$ 2,000$. & 40 \\
\hline $\begin{array}{l}\text { - People with some prior experience or knowledge of solar were more likely to be } \\
\text { interested in solar. Also, buyers of larger homes and those who are more } \\
\text { environmentally conscious. }\end{array}$ & 41 \\
\hline $\begin{array}{l}\text { - Biggest disadvantage was high initial cost - would not consider SWH if over } \\
\$ 2,000 \text {. Expect to pay } \$ 1,000 \text { to } \$ 1,500 \text {. }\end{array}$ & 42 \\
\hline $\begin{array}{l}\text { - Major drivers of consumer preference: } \\
\text { - System capacity (at least } 70-80 \% \text { of needs) } \\
\text { - Roof location } \\
\text { - } \$ 1,000 \text { to } \$ 1,500\end{array}$ & 42 \\
\hline $\begin{array}{l}\text { - Other desires of consumers: } \\
\text { - Backing of local utility or nationally - known firm }\end{array}$ & 42 \\
\hline - Price and performance of solar water heater is very important. & 43 \\
\hline $\begin{array}{l}\text { - Success will depend upon manufacturers, builders, realtors and consumers. } \\
\text { Builders must be convinced that there is consumer interest. }\end{array}$ & 44 \\
\hline $\begin{array}{l}\text { FOCUS Marketing - Qualitative (FOCUS 2) } \\
\text { Focus group research with users and non-users of solar water heating. Users } \\
\text { in Phoenix and Sacramento. Non-users in Phoenix, Sacramento and Orlando }\end{array}$ & • \\
\hline \multicolumn{2}{|l|}{ FOCUS 2 Conclusions } \\
\hline $\begin{array}{l}\text { - Public needs education with regard to solar water heating - it's not a top of mind } \\
\text { product. Need to reverse negative associations. }\end{array}$ & 4 \\
\hline $\begin{array}{l}\text { - Short and long-term money savings are the key to selling solar water heating } \\
\text { systems. }\end{array}$ & 4 \\
\hline $\begin{array}{l}\text { - Industry must convince public that new systems come with a strong warranty and } \\
\text { are relatively maintenance free. }\end{array}$ & 4 \\
\hline $\begin{array}{l}\text { - Most agree that we should try to help the environment, it is worthwhile, but they } \\
\text { are not willing to pay a premium because they do not believe gas water heaters are } \\
\text { big polluters. }\end{array}$ & 5 \\
\hline $\begin{array}{l}\text { - Builders can have a big impact on the use of solar - making it standard or by } \\
\text { installing it in model homes with a convincing presentation of the long-term cost } \\
\text { savings. }\end{array}$ & 5 \\
\hline $\begin{array}{l}\text { - With no known brands in the industry, the reputation of the installer is important } \\
\text { to the buyer. }\end{array}$ & 6 \\
\hline - The new technology, smaller systems are much more attractive to the home buyer. & 6 \\
\hline - The solar users in the focus groups were satisfied with their solar experience. & 7 \\
\hline \multicolumn{2}{|l|}{ FOCUS 2 Recommendations } \\
\hline $\begin{array}{l}\text { - Incentive program for builders to develop communities with SWH; positive } \\
\text { experience of new home owners will create interest amongst owners of older } \\
\text { homes }\end{array}$ & 8 \\
\hline $\begin{array}{l}\text { - Develop and enforce strong state standards for installation of solar - will create } \\
\text { confidence with new solar buyers. }\end{array}$ & 8 \\
\hline $\begin{array}{l}\text { - Initial marketing efforts should be directed toward new home communities where } \\
\text { only electricity is available. (Solar offers larger economic advantage). }\end{array}$ & 8 \\
\hline $\begin{array}{l}\text { - Distribute solar water heaters in same channels as traditional gas and electric } \\
\text { heaters for greater consumer awareness. }\end{array}$ & 8 \\
\hline $\begin{array}{l}\text { - Develop information pieces showing advantage of solar to be distributed at home } \\
\text { shows, new home communities and retail outlets where water heaters are sold. }\end{array}$ & 8 \\
\hline
\end{tabular}




\begin{tabular}{|c|c|}
\hline $\begin{array}{l}\text { FOCUS Marketing - Quantitative (FOCUS 1) } \\
\text { Telephone interviews with } 300 \text { new home buyers - } 100 \text { each in Florida, } \\
\text { Arizona and California. These homes do not have solar water heaters. }\end{array}$ & \\
\hline \multicolumn{2}{|l|}{ FOCUS 1 Conclusions } \\
\hline $\begin{array}{l}\text { - Although } 90 \% \text { of respondents said they had heard of solar water heating, it was } \\
\text { not "top of mind". }\end{array}$ & 3 \\
\hline $\begin{array}{l}\text { - Builders are not currently doing much to help the solar industry, but they could be } \\
\text { a big help. } \\
\text { - Over } 40 \% \text { of survey respondents agree solar should be standard equipment on } \\
\text { all new homes. } \\
\text { - } 40 \% \text { would pay an average of } \$ 21.60 \text { additional on their monthly mortgage. }\end{array}$ & 3 \\
\hline $\begin{array}{l}\text { - Key motivating factor to purchase solar is to save money, but many respondents } \\
\text { expressed some concern about the overall economics of solar. }\end{array}$ & 4 \\
\hline - Respondents showed interest in the newer types of solar water heating systems. & 4 \\
\hline \multicolumn{2}{|l|}{ FOCUS 1 Recommendations } \\
\hline $\begin{array}{l}\text { - Create a communications program to generate increased awareness in the newer } \\
\text { types of solar water heating systems. }\end{array}$ & 5 \\
\hline $\begin{array}{l}\text { - The primary message should be money savings, followed by a low maintenance } \\
\text { and strong warranty message. }\end{array}$ & 5 \\
\hline $\begin{array}{l}\text { Push builders to install solar as standard - buyers are favorable to the feature, even } \\
\text { though they would not currently know to ask for it. }\end{array}$ & 5 \\
\hline \multicolumn{2}{|l|}{$\begin{array}{l}\text { California Energy Commission (CEC) } \\
\text { Using the life-cycle cost of owning and operating a water heater, this study } \\
\text { compares the economics of various water heating systems in the Sacramento } \\
\text { area. Systems evaluated included electric resistance, natural gas, solar with } \\
\text { electric backup, solar with gas backup, and an electric heat pump. Two types } \\
\text { of solar systems are included: active and integral collector storage (ICS or } \\
\text { passive). }\end{array}$} \\
\hline Natural gas, when available, is less costly than electric water heating. & 1 \\
\hline $\begin{array}{l}\text { When natural gas is not available, a combined ICS-propane gas system is the least } \\
\text { cost option. }\end{array}$ & 1 \\
\hline $\begin{array}{l}\text { Among electric water heating systems, the least cost system is an ICS-electric system, } \\
\text { followed by an active solar-electric water heater system. }\end{array}$ & 1 \\
\hline $\begin{array}{l}\text { Solar water heater manufacturers can influence the economics of their systems by } \\
\text { increasing their efficiency and lowering the initial system costs. If they can do this } \\
\text { while keeping reliability high and maintenance low, they have the opportunity to } \\
\text { produce systems that are more cost-effective than simple gas water heating systems. }\end{array}$ & 2 \\
\hline
\end{tabular}




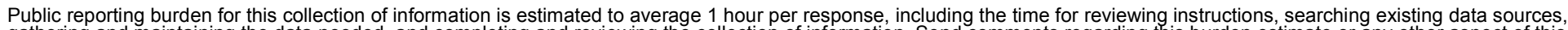

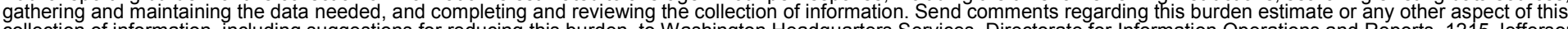

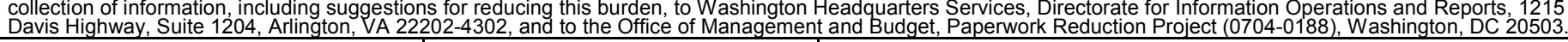

\begin{tabular}{|l|l|l|l}
\hline 1. AGENCY USE ONLY (Leave blank) & $\begin{array}{l}\text { 2. REPORT DATE } \\
\text { October } 1999\end{array}$ & $\begin{array}{l}\text { 3. REPORT TYPE AND DATES COVERED } \\
\text { Subcontract Report }\end{array}$ \\
\hline
\end{tabular}

4. TITLE AND SUBTITLE $\quad$ 5. FUNDING NUMBERS

A Comprehensive Review of Market Research on Solar Water Heaters

SH815004

6. $\operatorname{AUTHOR}(\mathrm{S})$

P. Ghent and C. Keller

7. PERFORMING ORGANIZATION NAME(S) AND ADDRESS(ES)

Focus Marketing Services

2899 Agoura Road, Ste. 223

Westlake Village, CA 91361

8. PERFORMING ORGANIZATION REPORT NUMBER

SR-550-27123

National Renewable Energy Laboratory

1617 Cole Boulevard

Golden, Colorado 80401-3393

9. SPONSORING/MONITORING AGENCY NAME(S) AND ADDRESS(ES)

U.S. Department of Energy

1000 Independence Ave., SW

Washington, DC 20585

10. SPONSORING/MONITORING AGENCY REPORT NUMBER

SR-550-27123

11. SUPPLEMENTARY NOTES

NREL Technical Monitor: Russell Hewett

12a. DISTRIBUTION/AVAILABILITY STATEMENT

12b. DISTRIBUTION CODE

National Technical Information Service

U.S. Department of Commerce

5285 Port Royal Road

Springfield, VA 22161

13. ABSTRACT (Maximum 200 words)

This is the second report of a four-task project to develop a marketing plan designed for businesses interested in marketing solar water heaters in the new home industry. The objective of this task is to identify key elements in previous studies on the marketing of solar water heaters in the new home industry. This review includes studies performed by FOCUS Marketing Services, the National Association of Home Builders Research Center, Symmetrics Marketing Corporation, and the California Energy Commission.

14. SUBJECT TERMS

water heating, solar water heating, marketing, business plan, solar energy, promotion

15. NUMBER OF PAGES

16. PRICE CODE

17. SECURITY CLASSIFICATION OF REPORT unclassified
18. SECURITY CLASSIFICATION OF THIS PAGE unclassified
19. SECURITY CLASSIFICATION OF ABSTRACT unclassified
20. LIMITATION OF ABSTRACT UL 